\title{
EFEKTIFITAS KINERJA GURU DALAM PENERAPAN PEMBELAJARAN KONTEKSTUAL MELALUI PEMANFAATAN KEANEKARAGAMAN HAYATI (KEHATI) DAN PROGRAMADIWIYATA DI SD N GIWANGAN
}

\author{
Siyam Mardini \\ Sekolah Dasar Negeri Giwangan \\ Email: siyammardini@yahoo.com
}

\begin{abstract}
Abstrak: SD N Giwangan sebagai sekolah Adiwiyata mempunyai lingkungan yang baik tetapibelum dimanfaatkan dalam pembelajaran. Berdasarkan hasil pengamatan ketika supervisi akademik, terdapat indikator yang rendah pada pelaksanaan pembelajaran kontekstual danpelaksanaan pembelajaran di luar kelas. Penelitian dilakukan kepada16 guru, untuk mengukur kinerja guru melalui supervisi pelaksanaan proses pembelajaran sebanyak 2 siklus. Teknik pengumpulan data melalui observasi, wawancara, dokumen, dan kuisener. Prosedur penelitian melalui perencanaan (planning), pelaksanaan (acting), pengamatan (observing), dan refleksi (reflecting). Indikator kinerja guru efektif, jika guru mampu menerapkan pembelajaran kontekstual yang dinilai dari hasil proses pelaksanaan pembelajaran dengan nilai minimal 85,00. Pembelajaran Kehati dan program Adiwiyata memberikan inspirasi baru kepada guru, untuk bisa mengembangkan materi ajar. Pendekatan kontekstual, berdampak siswa senang danaktif karena dilibatkan langsung mengelola lingkungan. Wawasan guru bertambah, guru mampu menyusun rencana pelaksanaan pembelajaran (RPP) dan menyajikan proses pembelajaran dengan sumber belajar lingkungan sekolah. Perubahan pola pikir dan kinerja guru, dapat meningkatkan kinerja guru. Indikator kinerja guru baik jika hasil supervisi proses pelaksanaan pembelajaran semua indikator dilaksanakan guru. Artinya, semua indikator dilaksanakan guru maka kinerja guru efektif. Berdasarkan hasil penelitian siklus I, bahwa pembelajaran kontekstual dan pembelajaran di luar kelas mencapai 62,50. Siklus I belum semua guru mempunyai kinerja baik. Sedangkan pada siklus II, guru yang menerapkan pembelajaran kontekstual dan pembelajaran di luar kelas telah mencapai 93,75. Berdasarkan hasil penelitiansiklus I dan II terdapat peningkatan 31,25, sehingga dapat disimpulkan bahwa efektifitas kinerja guru tercapai karena semua indikator dilaksanakan saat pelaksanaan proses pembelajaran. Pemanfaatan Kehati dan program Adiwiyata di SD N Giwangan berdampak pada kinerja guru menjadi lebih baik dan efektif.
\end{abstract}

Kata Kunci: Efektifitas, Kinerja Guru, Pembelajaran Kontekstual, Kehati dan Program Adiwiyata

\section{Pendahuluan}

Visi SD N Giwangan yaitu terwujudnya siswa SD Negeri Giwangan yang beriman, bertaqwa, berkharakter, berbudaya, berwawasan lingkungan, dan unggul dalam prestasi. Salah satu penekanan yang terkait ramah lingkungan adalah dalam pembiasaan siswa dan proses pembelajaran berwawasan lingkungan. Program sekolah menanamkan kebiasaan pada perilaku ramah lingkungan sejak masih duduk di kelas 1 . 
Pendidikan Lingkungan Hidup (PLH) yang terintegrasi dalam proses pembelajaran belum dilaksanakan oleh semua guru. Peran dan tanggung jawab semua guru di SD N Giwangan untuk mengelola lingkungan sekolah supaya dapat mewujudkan sebagai sekolah adiwiyata yang berkelanjutan. Penanaman dan pembentukan karakter perlu ditumbuhkembangkan dari kelas dan luar kelas oleh guru. Sesuai Permendikbud RI No. 23 tahun 2015 tentang Penumbuhan Budi Pekerti bahwa setiap sekolah seharusnya menjadi tempat yang nyaman dan inspiratif bagi siswa, guru, dan/atau tenaga kependidikan.

Pengelolaan lingkungan sekolah menjadi program utama sekolah dengan melibatkan semua guru. Keterlibatan guru dalam mengelola lingkungan sekolah akan membawa pengaruh besar dan cepat dalam menumbuhkembangkan karakter ramah dan peduli lingkungan sekolah. Implementasi pembelajaran yang ramah lingkungan dan daya dukung yang digunakan dalam implementasi pembelajaran termasuk perangkat pembelajaran, sarana dan prasarana perlu dilengkapi supaya berdaya guna secara maksimal.

Lingkungan sekolah merupakan lingkungan terdekat siswa selamabelajar di sekolah. Lingkungan sekolah menjadi salah satu sumber belajar siswa di sekolah. Di SD $\mathrm{N}$ Giwanganpelaksanaan proses pembelajaran di sekolah belum sesuai dengan harapan-harapan yang berbasis lingkungan. Proses pembelajaran di sekolah belum mengangkat isu-isu terkait lingkungan. Pengembangan dalam mengimplementasikan proses pembelajaran belum dilakukan oleh semua guru. Pembelajaran masih banyak yang belum mengaitkan dengan kondisi lingkungan sekitar.

Berdasarkan hasil supervisi akademik, saat guru melaksanakan proses pembelajaran di kelas ada dua indikator yang masih rendah yaitu indikator melaksanakan pembelajaran kontekstual dan melaksanakan pembelajaran di luar kelas. Pada saat pelaksanaan proses pembelajaran masih terdapat banyak guru belum melaksanakan pembelajaran kontekstual. Dua indikator tersebut dapat terpenuhi jika dalam pelaksanaan proses pembelajaran memanfaatkan lingkungan sekolah sebagai sumber belajar dalam proses pembelajaran. Memanfaatkan lingkungan sekolah untuk menumbuhkembangkan karakter siswa yang ramah dan peduli lingkungan. Pemanfaatan lingkungan sekolah dalam proses pembelajaran memberi ruang kepada guru untuk menerapkan model pembelajaran yang berbasis lingkungan.Pemanfaatan Kehati dan program Adiwiyata diintegrasikan dalam semua mata pelajaran. Komitmen sekolah,memanfaatkan Kehati dan program Adiwiyata supaya berhasil harus diterapkan dalam proses pembelajaran. Terdapat 
kesenjangan hasil, pada pelaksanaan proses pembelajaran kontekstual yaitu 25,00 melaksanakan pembelajaran kontekstual sedangkan 75,00 belum kontekstual. Begitu juga yang belum melaksanakan pembelajaran di luar kelas ada 87,00 sedangkan yang melaksanakan pembelajaran di luar kelas hanya 13,00.

Pembelajaran Kehatidan program Adiwiyata memberikan inspirasi yang baru kepada guru, untuk bisa mengembangkan materi ajar lebih luas dan mendalam supaya siswa lebih dekat dengan lingkungan sekolahnya. Pendekatan kontekstual membuat siswa senang dalam belajar karena siswa merasa tidak terbebani dengan tugas guru yang hanya belajar di dalam kelas. Proses pembelajaan membawa perubahan tidak hanya pada siswa tetapi juga karena terdapat peningkatan wawasan guru yang selama ini hanya banyak menggunakan sumber buku. Guru diharapkan mampu menyusun rencana pelaksanaan pembelajaran (RPP) dan menyajikan dalam proses pembelajaran dengan memanfaatkan lingkungan yang konstekstual.

Kenyataan bahwa tuntutan hidup manusia harus memahami berbagai kondisi lingkungan yang ditempati. Di sekolah siswa belajar berbagai masalah terkait lingkungan secara menyeluruh melalui beberapa mata pelajaran, misalnya IPS, IPA, Bahasa Indonesia, dan mungkin juga ada di mata pelajaran yang lainnya. Pengalaman belajar siswa tentang permasalahan lingkungan di sekitar tempat tinggalnya masih sedikit,hal ini akan mempersulit mengaitkan dengan materi ajar. Pemahaman dan pengembangan konsep,diperlukan teknik tertentu supaya siswa betul-betul memahami konsep materi ajar.

Perubahan pola pikir guru dalam proses pembelajaran yang lebih baik, dapat meningkatkan kinerja guru. Indikator kinerja guru baik jika hasil supervisi pelaksanaan proses pembelajaran semua indikator dalam instrumen terpenuhi dan dilaksanakan. Berdasarkan pengamatan yang dilakukan, efektifitas kinerja guru dalam penerapan pembelajaran kontekstual melalui pemanfaatan Kehati dan program Adiwiyata di SD N Giwangan memberikan warna berbeda karena siswa lebih semangat dalam belajar dan berlatih berkomunikasi antar teman. Selain itu, guru juga berusaha memenuhi indikator kinerja yang masih belum terpenuhi. Kinerja guru baik jika semua indikator terpenuhi atau dilakukan ketika mengajar.

Kinerja guru yang baik dapat dibuktikan melalui hasil supervisi pelaksanaan proses pembelajaran. Salah satu ciri guru profesional yaitu bahwa guru mempunyai kinerja minimal baik dan mempunyai kompetensi sebagai guru. Berdasarkan hasil supervisi pelaksanaan proses pembelajaran, bahwa saat guru melaksanakan proses pembelajaran di kelas, 
ada dua indikator yang masih rendah yaitu indikator melaksanakan pembelajaran kontekstual dan melaksanakan pembelajaran di luar kelas. Dua indikator tersebut dipenuhi dengan memanfaatkan lingkungan sekolah sebagai sumber belajar dalam proses pembelajaran. Memanfaatkan lingkungan sekolah untuk menumbuhkembangkan karakter siswa yang ramah dan peduli lingkungan. SD N Giwangan sebagai sekolah adiwiyata mempunyai lingkungan dengan beraneka ragam dan jenis tanaman belum dimanfaatkan dalam pembelajaran. Pemanfaatan lingkungan sekolah dalam proses pembelajaran memberi ruang kepada guru untuk menerapkan model pembelajaran yang berbasis lingkungan.

Pemanfataan lingkungan sekolah sebagai sumber belajar secara nyata akan memberi dampak positif kepada siswa. Pembentukan dan pembiasaan karakter ramah lingkungan dimulai dalam proses pembelajaran dengan sumber belajar alam sekitar di sekolah. Kondisi ini masih jarang dan sedikit dilakukanguru.

Isu pemanasan global atau global warming menjadi keprihatinan semua manusia di dunia. Gerakan ramah lingkungan melalui pembentukan dan pembiasaan siswa di sekolah perlu digiatkan dengan penyusunan program nyata. Sekolah memprogramkan dalam pembelajaran agar semua guru melakukan proses pembelajaran kontekstual dengan menekankan pemanfaatan Keanekaragaman Hayati (Kehati) yang berbasis adiwiyata di sekolah. Pemanfaatan Kehati dan program Adiwiyata diintegrasikan dalam semua mata pelajaran. Semua guru dalam proses pembelajaran memanfaatkan Kehati dan program Adiwiyata sebagai wujud program sekolah yang ramah lingkungan. Untuk mengukur keberhasilan dalam proses pembelajaran maka dilakukan supervisi pelaksanaan proses pembelajaran dengan penekanan pembelajaran kontekstual.

Berdasarkan hasil pengamatan ketika proses pembelajaran oleh guru bahwa penerapan pembelajarankontekstual di SD N Giwangan terdapat 25,00 sedangkan yang belum kontekstual 75,00. Hal tersebut diperkuat lagi dengan belum semua guru melaksanakan pembelajaran di luar kelas 87,00 sedangkan yang melaksanakan hanya 13,00. Berdasarkan kondisi tersebut, penerapan pembelajaran kontekstual melalui pemanfaatan Kehati dan program Adiwiyata efektif untuk mengetahui ketercapaian kinerja guru sudah baik atau belum. Siswa lebih semangat dalam belajar dan berlatih berkomunikasi antar teman. Selain itu guru juga berusaha memenuhi indikator kinerja yang masih belum terpenuhi. Kinerja guru baik jika semua indikator terpenuhi atau dilakukan ketika mengajar.

Berdasarkan latar belakang tersebut, maka rumusan masalah dalam penelitian adalah : Bagaimana efektifitas kinerja guru 
dalam penerapan pembelajaran kontekstual melalui pemanfaatan keanekaragaman hayati (Kehati) dan program Adiwiyata di SD N Giwangan? Tujuan penelitian untuk mengetahui efektifitas kinerja guru dalam penerapan pembelajaran kontekstual melalui pemanfaatan keanekaragaman hayati (Kehati) dan Program Adiwiyata di SD N Giwangan. Manfaat penelitianyaitu menanamkan karakter peduli lingkungankepada siswa dan guru mampu mengimplementasikan Kehati dan program Adiwiyata dalam pembelajaran kontekstual di SD N Giwangan.

Sekolah mempunyai program menghadirkan Kehati dalam proses pembelajaran. Kinerja guru adalah keseluruhan perilaku guru dalam mencapai tujuan terhadap pelaksanaan tugas yang dibebankan kepadanya baik sebagai pengajar, pelatih, pembimbing, pembinaan, dan pendidik siswa, sehingga dari penguasaan tugas pokok tersebut dapat meningkatkan kinerja guru dalam mengajar(Rudolf Kempa, 2015:8-9).

Pembelajaran

kontekstual menekankan pada proses keterlibatan siswa untuk menemukan materi sendiri, artinya proses belajar dikaitkan dengan pengalaman secara langsung. Harapannya dalam pembelajaran kontekstual siswa bisa mencari dan menemukan sendiri materi pelajaran.Siswa yang aktif belajar mencari dan menemukan sendiri akan mempunyai pengetahuan yang luas karena mempelajari ilmu secara utuh yang memiliki keterkaitan antara satu dengan yang lain. Pengetahuan yang diperoleh bukan hanya hafalan tetapi ilmu yang dipahami dan diyakini sendiri oleh siswa. Pemahaman Kehati mempermudah dalam menanamkan konsep pengetahuan. Tugas guru menyusun dan mengorganisir proses pembelajaran menggunakan sumber Kehati di sekolah.

Pengelolaan tanaman yang mendukung belajar siswa dilengkapi dengan Ruang Terbuka Hijau (RTH). RTH sangat dibutuhkan siswa sebagai sarana diskusi, belajar, dan bercengkerama. Desain RTH bisa menyesuaikan kebutuhan sekolah, dalam hal ini untuk mendukung kegiatan siswa dan guru. Berbagai tanaman, satwa air dan darat yang ada di sekolah mempunyai tujuan untuk membantu dan mempermudah belajar siswa sekaligus juga mempermudah guru dalam menyampaikan materi ajar terkait pemahaman konsep belajar. Pada prinsipnya, Kehati yang ada di sekolah diadakan dengan maksud memberi fasilitas, supaya siswa nyaman dalam belajar.

ProgramAdiwiyata di sekolah dituangkan dan dilaksanakan melalui aksi lingkungan di sekolah. Proses pembelajaran PLH dengan memanfaatkan sumber lingkungan dengan desain implementasi Kehati dan program Adiwiyata melalui pembelajaran kontekstual.Semua kebutuhan yang diperlukan dalam pembelajaran, 
disiapkan sekolah dan menganggarkan dalam APBS. Penganggaran bisa mencapai di atas 25\%, semua komponen dalam APBS wajib dipenuhi. Penyusunan program dan perangkat pembelajaran melibatkan tim adiwiyata. Susunan tim adiwiyata terdiri dari ketua, koordinator kegiatan, sekretaris, dan anggota yang menangani masing-masing komponen.

Implementasi dalam pelaksanaan proses pembelajaran memerlukan perangkat pembelajaran, gurumenyusun perangkat pembelajaran. Perangkat pembelajaran berupa silabus, menentukan Standar Kompetensi (SK) dan Kompetensi Dasar (KD) yang sesuai dan dapat diterapkan dalam PLH. Identifikasi SK dan KD memerlukan pencermatan khusus karena guru perlu menyiapkan materi ajar yang sesuai dengan SK dan KD dalam silabus. Penentuan SK, KD , dan materi yang sesuai akan dijabarkan dalam RPP. Penyusunan RPP disesuaikan dengan media dan sumber belajar yang akan digunakan.

Penentuan sumber belajar dengan memanfaatkan Kehati dan program Adiwiyata dalam pelaksanaan proses pembelajaran. Pemanfaatan Kehati dan program Adiwiyata di SD N Giwangan, guru perlu melakukan inovasi dan kreasi. Kreatifitas guru diperlukan dengan tujuan supaya siswa berperan aktif dalam pembelajaran. Aktifitas dalam proses pembelajaran terjadi interaksi belajar mengajar dalam suasana interaksi edukatif, yaitu interaksi yang sadar akan tujuan. Artinya interaksi yang telah dicanangkan untuk tujuan tertentu setidaknya adalah pencapaian tujuan pembelajaran yang telah dirumuskan. Kegiatan pembelajaran yang diprogramkan guru merupakan kegiatan integralistik antara pendidik dengan peserta didik (Endang Kumala, 2014 : 68).

\section{Metode Penelitian}

Penelitian ini merupakan Penelitian Tindakan Sekolah (PTS). Metode penelitian ini menggunakan metode kualitatif.Penelitian ini dilakukan dengan mencermati kondisi nyata yang terjadi dan dituangkan dalam bentuk deskripsi. Pelaksanaan penelitian dilakukan di SD N Giwangan, Jalan Tegalturi no. 45, Umbulharjo,Yogyakarta pada tahun ajaran 2016/2017. SD N Giwangan merupakan sekolah Adiwiyata Nasional pada tahun 2015, sehingga mempunyai lingkungan sekolah yang baik dan sangat mendukung untuk pembelajaran.Penelitian ini membutuhkan waktu 4 bulan, dengan perincian untuk persiapan, pelaksanaan, dan laporan.Fokus penelitianadalah pada proses pembelajaran ramah lingkungan dengan Kehati dan program Adiwiyata yang dilakukan oleh guru dan siswa.

Jenis datayang digunakan adalah kinerja guru diperoleh melalui supervisi akademik yang dilakukan oleh kepala sekolah kepada 16 guru pada tahun ajaran 
2015/2016 semester 2. Ada dua indikator yang rendah yaitu melaksanakan proses pembelajaran kontekstual dan pembelajaran di luar kelas. Teknik pengumpulan data; 1) teknik observasi dilakukan dengan melakukan pengamatan yang cermat dari awal sampai akhir proses penelitian, 2) wawancara digunakan untuk memperkuat data otentik dari guru dan siswa, 3) dokumen yang dibutuhkan dalam pembelajaran adalah dokumen guru berupa perangkat pembelajaran : kurikulum sekolah, APBS, Silabus,RPP, penilaian, dan foto-foto kegiatan yang dilaksanakan dalam pembelajaran, dan 4) kuisener dilakukan dengan menyediakan beberapa pertanyaan yang harus diisi oleh guru dengan menjawab "ya" atau "tidak".

Pengolahan datayang digunakan terdapat indikator yang rendah yaitu indikator melaksanakan proses pembelajaran kontekstual dan pembelajaran di luar kelas. Cara pengolahan data dengan menghitung jumlah guru yang disupervisi dibandingkan dua indikator tersebut. Hasil akhir penelitian dengan kategori kinerja guru efektif dalam penerapan pembelajaran kontekstual jika minimal 85,00 guru melaksanakan. Indikator keberhasilan harus menunjukkan perubahan yang nyata pada dua indikator yaitu pembelajaran kontekstual dan di luar kelas. Keberhasilan penelitian dapat dilihat pada hasil akhir supervisi memperoleh 85.00 guru dapat menerapkan semua indikator dalam pelaksanaan proses pembelajaran dan khususnya dua indikator yaitu melaksanakan proses pembelajaran kontekstual dan pembelajaran di luar kelas sesuai materi.

Kerangka berpikir menggunakan tahap-tahap perencanaan, pelaksanaan, pengamatan, dan refleksi. Dasar melakukan penelitian yaitu hasil supervisi tahun ajaran 2015/2016 semester 2 guru belum menerapkan pembelajaran kontekstual dan pembelajaran di luar kelas. Rencana penelitian pada setiap siklus menerapkan pembelajaran kontekstual dan pembelajaran di luar kelas.

\section{Hasil Penelitian dan Pembahasan}

\section{Hasil Penelitian}

Hasil pengamatan mencerminkan kondisi nyata yang dilakukan guru selama pelaksanaan pembelajaran.

a. Kondisi Awal

SD N Giwangan merupakan sekolah Adiwiyata dengan kurikulum teritegrasiada 12 rombongan belajar. Pada tahun ajaran 2016/2017 jumlah siswa SD N Giwangan 363 siswa. Jumlah guru kelas ada 12, guru Penjaskes ada 2, dan guru Pendidikan agama Islam ada 2. Sedangkan kegiatan ekstrakurikuler ada komputer, TPA, pramuka, seni lukis, seni tari, Bahasa Inggris, dan sepak takraw. Pelaksanaan pembelajaran konstektual dilakukan oleh guru kelas dan guru mata pelajaran. 
Proses pembelajaran masih berada di dalam kelas dan belum memanfaatkan lingkungan sekolah sebagai sumber belajar. SD N Giwangan sebagai sekolah Adiwiyata Nasional harus melaksanakan pembelajaran pendidikan lingkungan hidup terintegrasi dalam semua mata pelajaran. Kurikulum SD $\mathrm{N}$ Giwangan menyatakan bahwa pelaksanaan pendidikan lingkungan hidup terintegrasi dalam semua mata pelajaran sehingga pelaksanaannya melekat pada semua guru.

\section{b. Rencana Tindak}

Rencana tindak yang akan dilakukan dengan membuat jadwal atau program supervisi pada semester 1 tahun ajaran 2016/2017. Supervisi akan diberlakukan untuk semua guru kelas dan guru mata pelajaran. Waktu yang dibutuhkan untuk satu kali supervisi 2 jam pelajaran (70 menit).

Dokumen guru disampaikan kepada kepala sekolah sebelum pelaksanaan pembelajaran. RPP yang telah disusun guru digunakan sebagai pedoman pelaksanaan pembelajaran. Pengamatan dilakukan sebelum, selama, dan setelah proses pembelajaran. Hasil pengamatan akan direfleksikan untuk menyusun program perbaikan selanjutnya sampai tercapai indikator keberhasilannya.

\section{Pembahasan Hasil Penelitian}

Penelitian Tindakan Sekolah oleh Kepala sekolah di SD N Giwangan terbagi dalam dua siklus, data yang terkumpul melalui wawancara, observasi, kuisener dan dokumen. Penelitian yang dilakukan dimulai dengan melakukan observasi di beberapa kelas saat guru mengajar. Hasil penelitian yang sudah dilakukan perlu dilakukan pembahasan atau pengkajian secara mendalam melalui beberapa teknik yang sudah dilakukan. Pembahasan mendalam ini mengupas 2 kali siklus yang dilaksanakan dalam penelitian yaitu siklus I dan siklus II. Setiap siklus dibahas melalui 4 tahap yaitu Perencanaan (Planning), Pelaksanaan (Acting), Pengamatan (Observing), danReflkesi (Reflekting).

\section{a. Siklus I}

1) Perencanaan (planning)

Pada tahap perencanaan ini kepala sekolah sebagai peneliti melakukan sosialisasi dan komunikasi intensif kepada semua guru tentang penerapan pembelajaran kontekstual dengan pemanfataan kehati dan program adiwayata. Guru menyusun RPP yang akan digunakan dan skenario pembelajarannya. Penyusunan RPP dengan mengintegrasikan Kehati dan program Adiwiyata sekolah sesuai materi ajar. RPP yang sudah selesai wajib dimintakan tanda tangan kepala sekolah. Komponen RPP harus sesuai standar proses yang di dalamnya terdapat tiga kegiatan yaitu kegiatan pendahuluan, inti, dan penutup. Peneliti melakukan pengkajian terhadap RPP yang disusun guru. Semua RPP yang sudah 
melalui pengkajian dikembalikan kepada guru untuk selanjutnya digunakan dalam pembelajaran. Pada kegiatan ini masih ada 5 guru yang belum siap RPP sedangkan 11 guru sudah menyusun RPP.

Skenario pembelajaran wajib disampaikan oleh guru sebelum pembelajaran dilakukan supaya pembelajaran lebih terarah dan siswa mengetahui proses yang akan dilakukan. Semua guru mampu menyusun skenario proses pembelajaran dan menyampaikan skenario pembelajaran sebelum dimulai proses pembelajaran lebih lanjut.

Peneliti menyusun instrumen penelitian yang terdiri dari pengamatan untuk semua guru pada saat proses pembelajaran. Instrumen yang akan digunakan yaitu isntrumen supervisi pelaksanaan proses pembelajaran dan kuisener pelaksanaan pembelajaran.Menyusun kisi-kisi berfungsi sebagai acuan atau pedoman yang akan dilakukan dalam melakukan penelitian. Melalui kisi-kisi juga akan dilakukan kajian mendalam tentang berbagai permasalahan yang muncul serta solusinya.

\section{b. Pelaksanaan (acting)}

Skenario penting disampaikan sebagai rambu-rambu dalam melaksanakan pembelajaran. Guru melakukan pembelajaran sesuai skenario yang telah ditetapkan dalam RPP. Pada saat pelaksanaan proses pembelajaran ada 8 guru atau 50,00 yang sudah menyampaikan skenario pembelajaran sedangkan 8 guru atau 50,00 belum menyampaikan skenario pembelajaran. Penyampaian skenario pembelajaran dengan menghubungkan materi ajar dan kegiatan yang akan dilakukan.

Mendampingi proses belajar selama pembelajaran berlangsung guru mendampimgi siswa sampai tuntas. Pada tahap ini guru melakukan pendampingan di kelas dan di luar kelas. Guru mendampingi dan memantau semua kegiatan yang dilakukan siswa. Kegiatan yang dilakukan oleh siswa di luar kelas bervariasi ada yang merupakan kegiatan individu dan ada yang berkelompok.Guru mengkondisikan kelas supaya semua siswa siap mengikuti proses pembelajaran. Guru mengawali pendahuluan dengan berdoa bersama yang dipimpin oleh ketua kelas. Guru juga memberikan motivasi dengan cara menanyakan siswa yang tidak hadir, menyampaikan tujuan, menanyakan pengalaman hasil belajar.

\section{c. Pengamatan (observing)}

Berdasarkan instrumen yang sudah disusun maka pada kegiatan observasi ini pengamatan benar-benar dilakukan. Pengamatan dilakukan pada saat sebelum pembelajaran, saat pembelajaran, dan sesudah pengamatan pembelajaran. Pengamatan sebelum pembelajaran berfungsi untuk mempersiapkan RPP dan perangkat pembelajaran yang dibutuhkan 
yang akan digunakan di kelas. Dokumen kelengkapan mengajar harus sudah siap. Pada saat ini terjadi komunikasi antara guru dan kepala sekolah sebagai peneliti. Peneliti menanyakan lagi kepada guru tentang kesiapan mengajar.

Pada saat proses pembelajaran dilakukan pencermatan mendalam melalui dokumen dan instrumen pengamatan. Instrumen digunakan untuk mendapatkan data yang lebih lengkap dalam penelitian. Dokumen dan catatan lapangan digunakan untuk memperkuat data hasil pengamatan. Aktifitas guru dan siswa dalam proses pembelajaran dicermati dan dicatat untuk dijadikan jurnal kegiatan dalam proses pembelajaran. Proses pembelajaran dilakukan oleh guru untuk setiap pertemuan 2 jam pelajaran (70 menit).

\section{Pertemuan pertama}

Penelitian dilakukan kepada semua guru kelas, guru mata pelajaran, dan guru ekstrakurikuler. Pengamatan dilakukan selama 2 jam pelajaran di kelas 1-6 disesuaikan dengan Standar Kompetensi, Kompetensi Dasar, dan materi ajar. Hasil pengamatan aktifitas selama proses pembelajaran terkait pelaksanaan pembelajaran di luar kelas dan melaksanakan pembelajaran kontekstual terdapat 8 guru atau 50, 00 telah melaksanakan, sedangkan 8 guru atau 50.00 belum melaksanakan pembelajaran diluar kelas dan belum kontekstual.
Berdasarkan data hasil supervisi ada 6 guru kelas yang melaksanakan pembelajaran kontekstual dan di luar kelas, dan 2 guru mata pelajaran yaitu guru Pendidikan Jasmani. Sementara 8 guru lainnya belum melaksanakan, hal ini juga dicocokkan dengan RPP guru belum. Hasil pengamatan tersebut disampaikan kepada semua guru setelah mengajar dan guru cukup memahami maksud dalam kegiatan tersebut. Berdasarkan pengakuan guru memang masih bingung dalam melaksanakan pembelajaran kontekstual dan di luar kelas. Pada pertemuan kedua pengamatan dilakukan jarak satu minggu agar guru dapat mempersiapkan kegiatan yang akan dilakukan. Data hasil supervisi proses pembelajaran yang dilakukan guru pada pertemuan pertama siklus I.

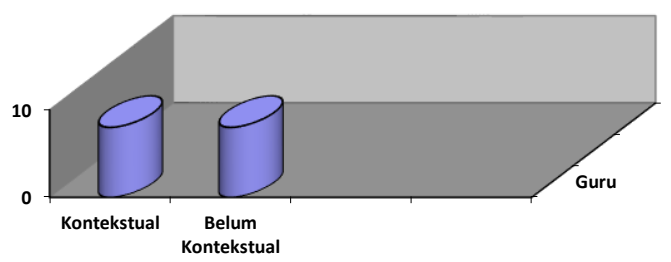

Gambar 1. Diagram Hasil Pembelajaran

\section{Pertemuan kedua}

Pada pertemuan kedua ada perbedaan dalam pelaksanaan pengamatan. Pengamatan dimulai untuk 8 guru yang belum melaksanakan pembelajaran kontekstual dan di luar kelas, kemudian pengamatan dilanjutkkan kepada 8 guru yang sudah melaksanakan tetapi RPP berbeda. Pengamatan dilakukan lebih jeli 
dan detail terkait indikator yang belum dilaksnakan guru. Indikator yang sudah bagus dikuatkan dengan memberikan apresiasi pada saat diskusi bersama guru.

Hasil pengamatan pada pertemuan kedua guru yang melaksanakan pembelajaran kontekstual dan di luar kelas ada 10 guru atau 62,50. Masih ada 6 guru atau 37,50 belum melaksanakan pembelajaran kontekstual dan di luar kelas. Berdasarkan hasil tersebut, maka perlu ada penguatan pada indikator yang bagus dan pendampingan lebih pada indikator yang belum terpenuhi.

Hasil komunikasi dengan guru yang belum mampu melaksanakan ada dua perbedaan. Pertama, ada 2 guru yang merasa bingung karena menganggap Standar Kompetensinya tidak bisa dimasukkan untuk pembelajaran kontekstual. Kedua, ada 4 guru yang sudah senior umurnya merasa tidak mampu menyusun RPP dan melaksanakan. Kepala sekolah sebagai peneliti menyarankan dan memotivasi guru agar selalu mengikuti perkembangan karena guru sebagai guru pembelajar yang harus selalu mengupdate ilmunya. Data hasil supervisi proses pembelajaran yang dilakukan guru pada pertemuan kedua siklus I.

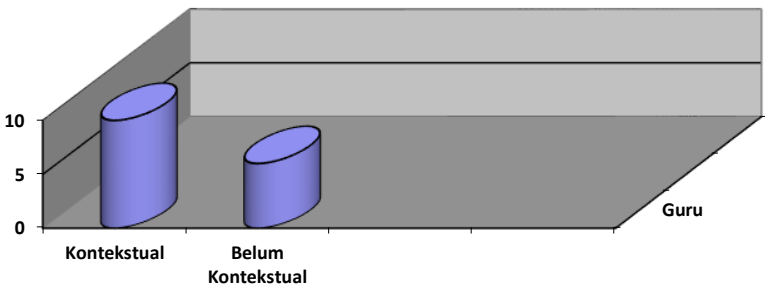

Gambar 2. Diagram Hasil Pembelajaran

d. Refleksi (reflekting)

Hasil penelitian pada siklus I masih perlu dilakukan tindak lanjut siklus 2 , hal ini karena belum semua guru mampu menerapkan pembelajaran kontekstual dan di luar kelas. Penekanan penelitian adalah pemanfaatan Kehati dan program Adiwiyata. Berdasarkan hasil proses pembelajaran di siklus I dalam pembelajaran kontekstual dan di luar kelas belum dilakukan oleh minimal 85,00 guru SD N Giwangan.

\section{b. Siklus 2}

Siklus kedua dilakukan dengan melakukan penyusunan jadwal dan kegiatan disesuaikan kondisi dan hal-hal yang masih perlu perbaikan dan penekanan dalam penelitian.

\section{1) Perencanaan (planning)}

Semua guru wajib menyusun RPP yang akan dilaksanakan dengan terlebih dahulu dikonsultasikan antar teman sejawat. Diskusi dengan teman sejawat baik dilakukan guru supaya bisa saling melengkapi kekurangan dan memberi yang lebih. Bagi guru yang pada siklus I sudah mampu menyusun RPP dan mampu 
melaksanakan dalam pembelajaran, wajib membantu guru yang belum mampu menyusun RPP. Dalam kegiatan ini peneliti menerapkan belajar antar teman sejawat di sekolah.

Guru sebagai guru pembelajar menerapkan tutor teman sejawat sebagai sumber belajar. Ada dua alternatif model belajar yang dipilih guru yaitu belajar antar teman sejawat, maksudnya ada yang melalui diskusi/ konsultasi dan ada yang melakukan kunjungan kelas mengamati proses pembelajaran yang dilakukan di kelas lain. Tutor teman sejawat dilakukan oleh guru agama Islam dengan guru Penjas, sedangkan guru kelas 4 mengunjungi kelas 3 . Guru kelas dua belajar melalui diskusi dengan kepala sekolah.

2) Pelaksanaan (acting)

Masing-masing guru melaksanakan proses pembelajaran sesuai skenario dalam RPP. Selama pelaksanaan proses pembelajaran guru mengelola kelas dan memfasilitasi siswa dalam belajar. Siswa diajak melakukan unjuk kerja langsung sesuai informasi guru. Guru menggunakan variasi metode dengan maksud supaya siswa aktif dan senang dalam belajar. Unjuk kerja terlihat di lakukan di kelas 6 A,B, kelas 5 A, kelas 3 A,B. Guru memantau dengan cara menghampiri antara siswa satu dengan lainnya ketika belajar di luar kelas. c. Pengamatan (observing)

Kegiatan pengamatan dilakukan di kelas 1-6 secara berurutan dimulai dari kelas 6 kemudian menurun sampai kelas 1 dan dilanjutkan guru bidang studi.

\section{Pertemuan pertama}

Hasil pengamatan pada pertemuan pertama guru lebih memahami maksud dalam pembelajaran yang akan dilakukan yaitu kontekstual dan di luar kelas. pengamatan pembelajaran dmulai dari kelas 6 terlebih dahulu. Pada kegiatan pengamatan di kelas, semua kelas sudah melaksanakan pembelajaran kontekstual dan di luar kelas. Skenario pembelajaran dalam RPP juga sudah memasukkan kontekstual. Data hasil supervisi proses pembelajaran yang dilakukan guru pada pertemuan pertama siklus II.

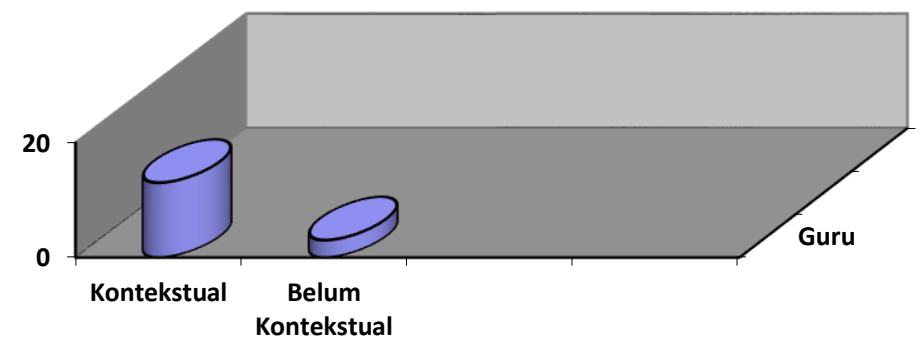

Gambar 3. Diagram Hasil Pembelajaran

\section{Pertemuan kedua}

Hasil pengamatan pelaksanaan proses pembelajaran di SD N Giwangan dari kelas $1-6$ melaksanakan pembelajaran yang sudah didiskusikan pada pertemuan sebelumnya. Kegiatan pembelajaran oleh 
semua guru dapat disimpulkan bahwa semua guru sudah mampu menerapkan pembelajaran kontekstual. Pada pertemuan kedua, guru sudah lebih mantap dalam melakukan pembelajaran. Dari 16 guru yang ada di SD N Giwangan menyatakan senang melakukan pembelajaran kontekstual dan di luar kelas. Alasannya, selain menanamkan konsep dan pembentukan karakter juga memberi ruang gerak kepada siswa supaya sehat tidak malas.

Pada pertemuan kedua siswa dan guru telah menyiapkan secara lebih baik. Guru sudah tidak lagi mengamati di kelas lain, tetapi tetap masih melakukan konsultasi antar teman dengan tujuan membangun kepercayaan diri sebelum mengajar. RPP guru sudah memuat pembelajaran kontekstual dan di luar kelas, guru juga mampu menyusun skenario pembelajaran dalam RPP dengan benar.

Guru mampu menyusun skenario pembelajaran kontekstual dengan urutan pembelajaran yang manis tertata dan terstruktur. Guru mampu memfasilitasi pembelajaran dan mengelola pembelajaran dengan benar sesuai skenario RPP. Berdasarkan hasil pengamatan, 16 guru mampu melaksanakan pembelajaran kontekstual dan di luar kelas dengan memanfaatkan Kehati dan program Adiwiyata dalam pembelajaran. Bahkan siswa senang mampu mengekspresikan diri melalui berbagai mata pelajaran yang dipelajari.

Kesimpulan pada pertemuan kedua adalah sebanyak 93,75 guru sudah mampu melaksnakan pembelajaran dengan memanfaatkan Kehati dan program Adiwiyata secara kontekstual. Satu guru purna tugas diganti oleh guru pendamping khusus yaitu di kelas 2 A. Sehingga di kelas 2 A guru kelas tidak melaksanakan karena ada kendala kesehatan dan mulai 1 Nofember 2016 sudah purna tugas.

Data hasil supervisi proses pembelajaran yang dilakukan guru pada pertemuan kedua siklus II.

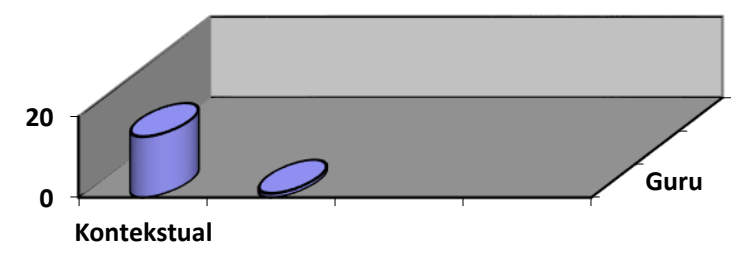

Gambar 4. Diagram Hasil Pembelajaran

d. Refleksi (reflecting)

Berdasarkan hasil siklus I dan II dan melalui pengumpulan data selama 4 bulan telah dihimpun kesimpulan akhir dalam penelitian. Kesimpulan dalam penelitian adalah bahwa guru telah melaksanakan pembelajaran kontekstual dan di luar kelas. Sampai pada siklus II telah dihimpun data dari 16 guru SD N Giwangan yang telah melaksanakan pembelajaran kontekstual dan di luar kelas ada 15 guru. Ini artinya bahwa 
guru SD N Giwangan yang belum melakukan pembelajaran kontekstual dan di luar kelas hanya 1 guru. Maka dapat disimpulkan bahwa Penerapan Pembelajaran Kontekstual Melalui Pemanfaatan Kehati dan Program Adiwiyata di Sekolah sangat efektif diterapkan.

Berdasarkan data supervisi pelaksanaan proses pembelajaran bahwa, guru yang menerapkan pembelajaran kontekstual dan di luar kelas telah mencapai 93,75. Artinya 93,75 guru sudah mampu melaksanakan pembelajaran dengan memanfaatkan Kehati dan program Adiwiyata secara kontekstual, sedangkan 16,25 tidak menerapkan bukan karena tidak mampu tetapi karena mulai tanggal 1 Nofember guru tersebut purna tugas. Hal ini berarti, penerapan pembelajaran kontekstual melalui pemanfataan Kehati dan program Adiwiyata di SD N Giwangan efektif dilaksanakan untuk mengukur kinerja.

\section{Simpulan}

Peningkatan mutu pendidikan pada umumnya diimbangi dengan peningkatan layanan. Layanan yang baik harapannya akan menghasilkan siswa yang berkualitas dan berprestasi dalam semua bidang. Layanan pendidikan di sekolah menyangkut layanan yang diberikan guru kepada siswa. Hal ini dapat berupa pendampingan belajar oleh guru kepada siswa dalam bentuk proses pembelajaran atau menambah jam mengajar.
Seiring tuntutan peningkatan mutu dan layanan tersebut sekolah selalu melakukan evaluasi terhadap semua kegiatan termasuk sekolah melakukan evaluasi terhadap hasil supervisi guru. Setiap hasil supervisi disampaikan kepada guru, agar dapat dijadikan bahan masukan perbaikan pembelajaran atau penguatan bagi yang sudah baik.

Diperlukan kinerja guru yang baik untuk mencapai tujuan peningkatan mutu dan layanan pendidikan di SD N Giwangan. Pengukuran kinerja guru, salah satunya melalui supervisi di kelas. Supervisi proses pembelajaran yang dilakukan kepada semua guru kelas dan mata pelajaran. Program supervisi proses pembelajaran dilakukan dengan penyusunan jadwal pelaksanaan.

Tuntutan mutu sekolah harus diimbangi dengan kinerja guru pula. Kinerja guru yang baik, akan memberi tauladan yang baik kepada siswa. Tuntutan kinerja guru harus dilakukan seiring dengan beberapa regulasi pemerintah tentang pendidikan. Sesuai visi SD N Giwangan untuk mencapai prestasi siswa dan sekolah maka kinerja guru harus selalu baik. Proses pembelajaran yang dilakukan guru merupakan salah satu cara untuk mengukur ketercapaian kinerja guru. Kinerja guru baik jika semua indikator dalam instrumen supervisi dilaksanakan dan mempunyai nilai baik. Artinya dalam proses pembelajaran semua unsur harus baik dimulai dari perencanaan sampai penilaian 
belajar. Guru harus mampu menyusun RPP dan menyusun skenario pembelajaran kontekstual dengan memanfaatkan lingkungan sekolah sebagai sumber belajar. SD N Giwangan sebagai sekolah Adiwiyata mempunyai aneka ragam tanaman yang dapat dimanfaatkan dalam pembelajaran.

Hasil penelitian di SD N Giwangan menunjukkan adanya perubahan perilaku guru dalam proses pembelajaran. Perubahan perilaku guru dalam proses pembelajaran menunjukkan bahwa guru mempunyai keinginan memperbaiki kinerja untuk lebih baik. Penerapan pembelajaran kontekstual dengan memanfaatkan Kehati dan program Adiwiyata sekolah diharapkan efektif untuk meningkatkan kinerja guru. Berdasarkan hasil penelitian dapat disimpulkan sebagai berikut :1) Penerapan pembelajaran kontekstual melalui pemanfaatan Kehati dan program Adiwiyata di SD N Giwangan dilaksanakan secara terintegrasi dalam semua mata pelajaran. Guru termotivasi untuk selalu belajar dan meningkatkan kinerjanya. Kenerja guru dalam proses pembelajaran diukur melalui supervisi oleh kepala sekolah dengan nilai minimal "Baik", 2) Efektifitas kinerja guru tercapai, hal ini diperkuat dengan hasil proses pembelajaran yang dilakukan oleh guru. Guru mampu menerapkan pembelajaran kontekstual melalui pemanfaatan Kehati dan program Adiwiyata di sekolah dapat tercapai.
Guru menyiapkan silabus, RPP sampai penilaian terintegrasi dengan PLH. Pendidikan Lingkungan Hidup (PLH) di SD $\mathrm{N}$ Giwangan melalui pembelajaran terintegrasi dalam semua mata pelajaran. Langkah awal yang dilakukan sekolah membetuk tim adiwiyata yang terdiri guruguru kelas dan mata pelajaran untuk terlibat menyusun kurikulum dan kegiatan di sekolah. Tugas tim menyusun dan menyiapkan bahan ajar, jadwal dan program kegiatan, dan aksi nyata dalam mengelola lingkungan.

Penyusunan bahan ajar dengan menyiapkan silabus dan RPP yang terkait dengan lingkungan untuk dilaksanakan dalam setiap pembelajaran di sekolah. Jadwal dan program kegiatan yang akan dilaksanakan disesuaikan Standar Kompetensi, Kompetensi Dasar, dan materi yang akan diajarkan. RPP yang disusun oleh guru wajib mencantumkan proses pembelajaran sampai penilaian untuk pembentukan dan pembiasaan ramah lingkungan. Semua kebutuhan yang diperlukan dalam pembelajaran, disiapkan sekolah dan menganggarkan dalam APBS.

Hasil penelitian akhir menunjukkan bahwa guru yang melaksanakan pembelajaran kontekstual dan di luar kelas telah mencapai 93,75. Artinya guru sudah mampu melaksanakan pembelajaran dengan memanfaatkan Kehati dan program Adiwiyata secara kontekstual. Hal ini berarti, 
penerapan pembelajaran kontekstual melalui pemanfataan Kehati dan program Adiwiyata di SD N Giwangan kinerja guru dapat diukur dan efektif dilaksanakan. Guru sudah mampu menyusun RPP dan mengimplementasikan pemanfaatan Kehati dan program Adiwiyata dalam proses pembelajaran. Pemanfaatan lingkungan sekolah sebagai sumber belajar sangat menyenangkan bagi siswa.

Berdasarkan hasil penelitian dan kesimpulan di atas perlu disampaikan beberapa saran dan rekomendasi yaitu : 1) Guru sebagai agen pembelajar dan duta ilmu harus mempunyai kinerja yang baik. Kinerja guru harus selalu ditingkatkan dengan alat ukur bermacam-macam. Supervisi sebagai alat untuk memperbaiki proses pembelajaran selanjutnya. Tujuannya agar efektifitas kinerja guru dapat berjalan secara terus menerus dan berkesinambungan jika supervisi proses pembelajaran dilaksanakan secara rutin. Guru harus selalu meningkatkan pengetahuan karena guru pembelajar harus selalu mengupdate kemampuann, 2) Dasar pengambilan kebijakan terkait pemenuhan standar minimal di sekolah. Kepala sekolah memberi fasilitas dan pemenuhan kebutuhan siswa dan guru untuk meningkatkan mutu belajar dan pendidikan di SD N Giwangan. Penelitian juga menjadi dasar penyusunan kebijakan di lingkungan sekolah terkait kurikulum dan APBS di SD N Giwangan, 3) Pengawas sebagai pembina sekolah memberi dorongan dan pemantauan terkait kinerja guru dan kepala sekolah untuk meningkatkan mutu sekolah.

\section{DAFTAR PUSTAKA}

Akhmad Muhaimin. 2014. Menjadi Guru Favorit. Jakarta : Ar-Ruzz Media

Endang Komara. 2014. Belajar dan Pembelajaran Interaktif. Bandung : PT. Refika Aditama

George Boeree. 2008. Metode Pembelajaran dan Pengajaran. Jakarta : Ar-Ruzz Media

Jamal Ma'mur Asmani. 2012. Tips Efektif Supervisi Pendidikan Sekolah. Jogjakarta: Diva Press

Nurani Soyomukti. 2013. Teori-teori Pendidikan. Jakarta: Ar-Ruzz Media.

Mulyasa. 2016. Manajemen dan Kepemimpinan Kepala Sekolah. Jakarta : Bumi Aksara

Peraturan Menteri Pendidikan dan Kebudayaan No. 20 tahun 2016. Standar Kompetensi Lulusan. Jakarta : Kemendikbud.

Peraturan Menteri Pendidikan dan Kebudayaan No. 21 tahun 2016. Standar Isi. Jakarta : Kemendikbud

Peraturan Menteri Pendidikan dan Kebudayaan No. 22 tahun 2016. Standar Proses. Jakarta : Kemendikbud

Peraturan Menteri Pendidikan dan Kebudayaan No. 23 tahun 2016. Standar Penilaian. Jakarta : Kemendikbud 
Rudolf Kempa.2015. Kepemimpinan Kepala

Sekolah. Yogyakarta: Penerbit

Ombah

http://id.m.wikipedia.org diambil pada hari Sabtu, 13 Agustus 2016 pukul 14.00 WIB. 